\title{
COMPLEMENTARY NARRATIVE COMMENTARIES OF STATUTORY \\ ACCOUNTS IN ANNUAL REPORTS OF UK LISTED COMPANIES
}

\author{
VENANCIO TAURINGANA AND MUSA MANGENA*
}

\footnotetext{
* The authors are respectively Senior Lecturer in Accounting \& Finance at Bournemouth University, Centre for Corporate Governance \& Regulation, and Lecturer in Accounting, Bradford University School of Management. We would like to acknowledge the helpful comments and suggestions by two anonymous reviewers. Correspondence should be addressed to Dr Venancio Tauringana, Senior Lecturer in Accounting \& Finance, Bournemouth University, Centre for Corporate Governance \& Regulation, Fern Barrow, Poole, Dorset, BH12 5BB. UK. E-mail:vtauringana@bournemouth.ac.uk
} 


\title{
COMPLEMENTARY NARRATIVE COMMENTARIES OF STATUTORY ACCOUNTS IN ANNUAL REPORTS OF UK LISTED COMPANIES
}

\begin{abstract}
This paper, for the first time, classifies narrative information into complementary and supplementary. For the purpose of the paper, complementary narrative information is defined as that information which refers to specific numbers presented in the statutory accounts (profit and loss and balance sheet). Non-specific narrative information is classified as supplementary. Having made the distinction and provided reasons for such a distinction the paper investigates the extent of complementary narrative commentaries on numbers from the statutory accounts. The paper also investigates which company-specific characteristics are associated with the extent of complementary narrative commentaries. An index consisting of 46 items which must be reported in the statutory accounts was used to measure the extent of complementary narrative commentaries in the annual reports of 170 listed UK companies. The findings suggest that, on average, the companies comment on 39.9\% of the numbers appearing in their statutory accounts. Using the Ordinary Least Squares (OLS) regression model, the results indicate that company size, gearing, profitability, liquidity ratio, the presence of exceptional items, and substantial institutional investment are significantly associated with the extent of complementary narrative commentaries. However, auditor type, directors' share ownership, and the proportion of non-executive to executive directors are not significantly associated with the extent of complementary narrative commentaries. The research has important implications for accounting regulators, users of annual reports and future research into the usefulness narrative information provided in annual reports.
\end{abstract}

Key words: Complementary, supplementary, narratives, commentaries, statutory accounts, annual reports. 


\section{COMPLEMENTARY NARRATIVE COMMENTARIES OF STATUTORY ACCOUNTS IN ANNUAL REPORTS OF UK LISTED COMPANIES}

\section{Introduction}

The value of narrative information to users of annual reports is well documented in accounting literature (see, for example, Beattie, 1999; Rutherford, 2002, Beattie, McInnes and Fearnley, 2004). Previous studies in the UK (e.g., Lee and Tweedie, 1981; Bartlett and Chandler, 1997) show that narrative sections of annual reports, including the chairman's statement are the most read by both sophisticated and unsophisticated investors. Empirical research using US and Canadian data shows similar results. For example, Abrahamson and Amir (1996) documented that information provided in the president's letter was useful in identifying firms with better than expected future performances. Rodgers and Grant (1997) found that the Management Discussion and Analysis (MD\&A) section of annual reports provides the largest proportion of information cited by sell-side analysts in their reports, constituting almost twice as much information as basic financial statements. Additionally, Clarkson, Kao and Richardson (1999) revealed that MD\&A sections of reports are a source of both new and useful information to sell-side financial analysts, suggesting that narrative information is important to sophisticated users. Similarly, Barron and Kile (1999) also found that high quality MD\&A disclosures are associated with less error and dispersion in analysts’ earnings forecasts.

Accounting narratives have also been found to be useful in predicting bankruptcy. For example, Tennyson, Ingram and Dugan (1990) and Smith and Tafler (2000) investigated the relevance of accounting narratives in predicting company failure and found that narrative are useful in predicting which companies would fail. Efforts of regulatory authorise both in the US and UK also illustrate the importance of accounting narratives. The US Securities and Exchange Commission (SEC, 2002), for example, extended disclosure requirements in the MD\& A section because it was felt that such information is useful to users of the annual report. In the context of 
the UK, the Accounting Standards Board (ASB) advocated for mandatory Operating and Financial Review (OFR). Consequently, the ASB's 2005 reporting standard OFR was made a mandatory under Statutory Instrument (S.I. 2005/1011). However, this was repealed by the Companies Act 1985 (OFR) (Repeal) Regulations 2005. Further importance of narratives is evident from the requirements of the European Union Accounts Modernisation Directive (EU AMD, 2003) which now incorporates most of the information formerly required by ASB (2005). The increasing proportion of the UK annual reports dedicated to narrative information is a further reflection of the increasing importance of narratives. A survey by Arthur Andersen in 1996 and 2001, for example, found that a large proportion of annual report pages dedicated to narrative disclosures increased from 45\% in 1996 to 57\% in 2001.

This objective of this paper is to examine the extent of complementary narrative commentaries in annual reports of UK listed companies. The study also seeks to determine which company specific characteristics are associated with the extent of complementary narrative commentaries. We focus on complementary narrative information mainly because it is relatively easier to check its presence or absence by referring to financial statements compared to supplementary information.

According to ASB (2006) narrative information reported in the OFR should complement as well as supplement the financial statements, in order to enhance the overall corporate disclosure (emphasis added). This suggests that narrative information play either a complementary or supplementary role to the financial statements. What is complementary or supplementary narrative information is, however, not defined by ASB (2006). Indeed previous studies (e.g., Beattie, 1999, Rutherford, 2002) do not make a distinction between complementary and supplementary information'. We therefore, propose to formally classify narrative information into complementary and supplementary. We define complementary narrative information as that information that refers to specific accounting numbers presented 
in the financial statements. The objective of such information is to inform the reader why such numbers are lower, the same or higher compared to the previous period. Our definition is consistent with Cole and Jones (2005) who suggest that complementary information should clarify the information provided in the financial statements by providing explanations for, and data related to changes in revenue and expenses. Understanding why there has been an increase or decrease to items in the financial statements could be helpful for investment decisionmaking. For example, explaining changes in revenue and profits may assist investors in anticipating future revenue and profits as well as providing a picture on whether current trends will persist. Complementary narrative information in annual reports also helps investors; particularly the unsophisticated understand the company results presented in financial statements. Evidence from different countries that suggest that unsophisticated ordinary shareholders do not understand financial statements ( see for example, Lee and Tweedie (1976) and Bartlett and Chandler (1997) in the UK, Klassen and Schreuder (1981) in the Netherlands, Wilton and Tabb (1978) in New Zealand and Anderson (1979) and Courtis (1982) in Australia suggest that the problem transcends national boundaries.

On the other hand, we define supplementary narrative information as additional narrative information that does not refer to specific accounting numbers presented in financial statements. This includes non-specific narrative information on future prospects, company's strategy, and operating environment. Accordingly, to distinguish the two types of narrative information it is important to ask whether a word, phrase or sentence or paragraph is describing a specific figure that is presented in the financial statements. If the answer to that is yes then that information is complementary and if the answer is no then the information is supplementary. Although, supplementary information is non-specific it is still important in assisting investment decision process (Wilson and Allison-Koerber, 1992; Milne and Chan, 1999). 
We believe that this study, which makes a distinction of narrative information for the first time, is important to accounting policy makers, users of annual reports and for future research. First, narrative information is currently less regulated than financial statements. A possible reason is the difficulty in legislating for reporting of narrative information and enforcing compliance. Given that complementary narrative information refers to specific numbers in the financial statements, regulating such information and enforcing compliance should be easier than the case with supplementary information. For example, it is easier for accounting regulators to require complementary narrative commentary of material changes to turnover, profits, and long term loans and enforce because this can easily be checked. However, it is more difficult to legislate to enforce supplementary information such as company strategy; future plans etc and enforce compliance because there is no way of checking such information. Second, the availability of more complementary narrative information will benefit unsophisticated users who do not understand financial statements and rely on management interpretation of financial results for an appreciation of company performance. Sophisticated users such as analysts will also benefit as they try to understand factors affecting current performance in order to predict future results. Finally, we also believe that the study is important as it may form the basis of future accounting research that could lead to improvements in the quality of financial reporting. For example, the distinction should lead to research into the relative usefulness of narrative complementary and supplementary information.

The rest of the paper is organised as follows. The following section discusses the environment of complementary narrative commentaries. Section 3 examines the theoretical framework of complementary narrative commentaries and develops the hypotheses to be tested. This is followed in section 4 by a discussion of data and research methods. Section 5 presents and discusses the research results. Finally, Section 6 provides summary and concluding remarks. 


\section{Narrative Commentaries in the UK}

This section discusses the complementary narrative reporting environment in UK. However, as will become clear, it is always not possible to determine whether the requirements are for complementary or supplementary narrative information. This is because the existing legislation or recommendations do not recognise the distinction between complementary and supplementary narrative information. Our analysis of the legislation and recommendations should, however, be of some help in understanding to what extent companies are currently required to report complementary and supplementary information. The analysis should provide a context in which the results of the study are seen and interpreted.

There are various requirements in terms of reporting of narrative information in general. For example, The UK Companies Act (CA) 1985, requires 'a fair review of the development of the business of the company and its subsidiaries during the year and their position at the end of the year' [Sec 234 (1) (a)]. What is 'fair review' is open to interpretation by company management since it is not defined by the Act. Arguably a fair review of business would include discussion of the results which may include turnover and profits. To the extent that managers decide to discuss such figures as they appear in financial statements that would constitute complementary narrative commentary. The CA 85 also requires that 'the amount (if any) that directors recommend should be paid as dividend must be stated [s 234 (1)(b)] in the directors' report. Since the dividends recommended are also included in the financial statements we believe that this requirement relates to complementary narrative information. Finally, CA 85 also requires that differences between the market value of land held by the company or the group should be disclosed in the directors' report, if in the opinion of the directors the difference is such of a significance that it should be brought to shareholders' or debenture holders attention [7 sch 1 (2)]. Such a requirement is in our opinion complementary information assuming that the discussion relates to the value of land that is stated in the balance sheet. 
Under the European Union Accounts Modernisation Directive (EU AMD, 2003) companies are now required to produce an 'enhanced directors' report' incorporating a Business Review. The EU AMD (2003) requires that the Business Review should be a balanced and comprehensive analysis of the development, performance, and position of the company at the end of the year. Under the EU AMD (2003) regulations the review must include analysis using financial key performance indicators (KPI). The regulations do not say how many KPIs should be included, nor mandate any particular KPIs for companies to report on. The selection and number of KPIs included in the review is for directors to decide (Trucost, 2006).

Complementary narrative commentary has also been the subject a number of a number of previous pronouncements by the $\mathrm{ASB}^{1}$. 1n 2005, the ASB issued Reporting Standard (RS) 1 under its then legal powers to make standards for the OFR ('The Reporting Standards (Specified Body) Order 2005' (SI 2005 No. 692)). The legal requirements for the OFR were set out in 'The Companies Act 1985 (Operating and Financial Review and Directors' Report etc.) Regulations, 2005' (SI 2005 No. 1011). However, the legal nature of the OFR was short lived since it was repealed by 'The Companies Act 1985 (Operating and Financial Review) (Repeal) Regulations 2005 (SI 2005 No. 3442) which came into effect in January 2006. Following these developments the ASB converted RS 1 to a Reporting Statement which means that companies can still comply with the statement on a voluntary basis. The RS states that the OFR, where, relevant should provide additional explanations of amounts recorded and explain the conditions and events that shaped the information contained in the financial statements. The statement also suggests that the OFR should contain an analysis of financial position of the company. The analysis whilst based on financial statements, should comment on the events that have impacted the financial position of the entity during the financial year, and future factors that are likely to affect the financial position going forward. Finally, the RS also recommends that

\footnotetext{
${ }^{1}$ For example, The Operating and Financial Review (OFR) issued 1993 and revised 2003.
} 
the OFR should discuss the entity's current and prospective liquidity. Where relevant, this should include commentary on the level of borrowing.

\section{Theoretical Framework \& Hypotheses Development}

Given that complementary narrative commentaries of statutory accounts is largely voluntary, the extent of reporting such information might be driven by benefits and costs. Prior analytical research suggests that greater disclosure can help to correct a firm's undervaluation (Verrecchia, 1990) and also to correct overvaluation to avoid potential litigation (Skinner, 1994). Kim and Verrecchia (1994) suggest that greater disclosure reduces information asymmetry, thereby improving liquidity and lowering the cost of capital. According to Ronen and Livnat (1981), voluntary information such as complementary narrative commentaries might be provided if managers believe this would increase the wealth or expected utility of shareholders. Milgron (1981) also argued that disclosure may occur to signal good news on the part of the company. For example, managers reporting increased profits may wish to provide more complementary narrative commentaries to draw the attention of investors to increased profitability. Diamond (1985) showed analytically that firms will disclose information if it saves traders' the cost of acquiring it on their own and if it improves risk sharing by making traders' beliefs more homogeneous. Finally, Diamond and Verrechia (1991) linked disclosure such as that of complementary narrative commentaries to the cost of capital: revealing information to reduce information asymmetry can reduce a firm's cost of capital by attracting increased demand from large investors due to increased liquidity of the firm's securities.

However, Verrecchia (1990) also argued that given agency problems, investors may view disclosures as non-credible and therefore reduce the value of a company. Additionally, greater disclosures could reduce shareholder value by revealing valuable information to competitors, particularly for companies operating in high-growth or concentrated product markets (Bamber 
and Cheon, 1998). Therefore, to the extent that the benefits of complementary commentaries outweigh costs, managers are more likely to have incentives for additional complementary commentary on statutory accounts.

Drawing from the literature, prior empirical studies demonstrate that disclosure practices are motivated by a number of factors such as agency-related costs (Botosan and Harris, 2000) and corporate governance mechanisms (e.g., Haniffa and Cooke, 2002). This study draws from some of this literature to model the relationship between complementary narrative commentaries and company-specific variables. For convenience the variables are grouped into four categories, namely structure, performance, ownership, and governance related. According to Lang and Lundholm (1993), structural related variables (size and gearing) measure a firm’s characteristics which are widely known and likely to remain relatively stable over time, whilst performance variables (profitability, liquidity and exceptional items) are time-period specific, representing information to which management may have preferential access and is likely to be the subject of disclosure during the period. A further two categories proposed in this study relate to ownership (directors' share ownership and substantial institutional investors) and governance (auditor type and the proportion of non-executive directors) of the company. Ownership is an important category, given that the ASB (1999) identified the objective of annual reports as being to provide information about the financial position and performance of a company useful to many users (primarily investors). The governance category is also important since significant results will indicate the effectiveness of governance mechanisms in ensuring the reporting of information available internally to outsiders.

\subsection{Structure-Related Variables}

The structure-related variables discussed are company size and gearing. A number of previous studies suggested reasons why company size may influence the extent of disclosure. 
These include the competitive advantage of large companies being less endangered by greater disclosure (Belkaoui and Kahl, 1978); information costs (Firth, 1979); advice of well-qualified accounting staff and advisors; vulnerability of large firms to implicit and explicit government regulation (Gagnon, 1971); and political costs (Stigler, 1971). Others have also suggested that the complexity and operations of larger companies suggest they are likely to have sophisticated information systems for managerial control as well as the needs of creditors (Cooke, 1991). For similar reasons it is expected that large companies may provide more complementary narrative commentary of statutory accounts numbers than smaller companies.

The expectation of a relationship between gearing and complementary narrative commentary of statutory accounts is based on the theory that predicts higher agency costs for firms with proportionally more debt in their capital structures (e.g. Smith and Warner, 1979). Higher levels of complementary narrative commentary assure long-term creditors that management and shareholders are less likely to diminish claims accruing from bond covenants and thus reduce agency costs (Myres, 1971). In the absence of such assurances, long-term creditors may decide to price-protect themselves by demanding higher rates of return (Chow, 1982). However, Zarzeski (1996) argued that companies with high gearing tend to share more private information with creditors due to well-developed banking relationships which may result in less, rather than more, disclosure. El-Gazzar, Finn and Jacob (1999) also suggested that low-geared companies may disclose more rather than less information because they tend to depend on equity financing which could encourage greater disclosure to meet investor demands for information. Empirical evidence of the relationship between disclosure and gearing is similarly mixed. Malone, Fries and Jones (1993) found a significant positive relationship but Schwartz and Soo (1996) found a significant negative relationship, whilst others (e.g.Wallace and Naser, 1995) found no significant relationship. Given the mixed results from previous studies, no directional prediction of the relationship between gearing and complementary 
narrative commentary is made in this study. Based on the above literature, it is hypothesised that:

$\boldsymbol{H}_{1:} \quad$ There is a positive relationship between company size and the extent of complementary narrative commentary of statutory accounts.

$\boldsymbol{H}_{2:} \quad$ There is a relationship between gearing and the extent of complementary narrative commentary of statutory accounts.

\subsection{Performance-Related Variables}

The three performance-related variables are profitability, liquidity ratio and the presence of exceptional items. Previous studies (e.g. Buzby, 1975) have suggested that higher rates of return motivate management to disclose detailed information in order to support continuance of their positions and compensation. Signalling theory also suggests that more profitable companies are more likely to disclose more information to signal to the market their superior performance (see Akerlof, 1970) and differentiate themselves from poor performers. In the context of complementary narrative commentary, profitable companies are expected to provide extensive commentary on a number of indicators, such as profit before and after tax, dividends and earnings per share, to highlight their achievements compared to companies reporting declining profitability.

Liquidity ratio is also expected to be associated with complementary narrative commentary because company managers who have high liquidity ratios have nothing to hide from users of financial statements (Belkaoui and Kahl, 1978). Such companies may also volunteer complementary narrative commentary to counter allegations that their high liquidity position may be a sign of poor working capital management. In contrast, management of companies with low liquidity ratios may fear that by volunteering complementary narrative 
commentary of their liquidity positions, short-term creditors may demand immediate payment. This is because the ability of a firm to meet its short-term financial obligations without having to liquidate its long-term assets or cease operation is an important factor in interested parties such as investors, lenders and regulatory authorities evaluating it (Wallace and Naser, 1995). When a company is unable to pay its current liabilities (interest and capital) this is to the detriment of the lender who may in turn start bankruptcy proceedings.

Financial Reporting Standard (FRS 3, para. 5) defines exceptional items as 'material items which derive from events or transactions that fall within the ordinary activities of the reporting entity and which individually or, if of similar type, in aggregate, need to be disclosed by virtue of their size or incidence if the financial statements are to give a true and fair view'. The presence of such items in the financial statements is likely to motivate management to provide some complementary narrative commentary as to the reason why they arose. Failure to provide commentary could result in investor uncertainty about the prospects of the company which may result in volatility of its share price. Based on the above literature, it is hypothesised that:

$H_{3}$ : $\quad$ There is a positive relationship between profitability and the extent of complementary narrative commentary of statutory accounts.

$\mathrm{H}_{4}$ : $\quad$ There is a positive relationship between liquidity and the extent of complementary narrative commentary of statutory accounts.

$H_{5}: \quad$ There is a positive relationship between the presence of exceptional items and the extent of complementary narrative commentary of statutory accounts. 


\subsection{Ownership-Related Variables}

Executive directors' share ownership has been linked to differences in disclosure levels because agency costs are associated with an increasing level of non-owner management in a firm (Leftwich, Watts and Zimmerman, 1981). Provision of additional information to the principals (shareholders) about the outcomes of management (directors) decisions made by the agent on the principals' behalf reduces agency costs (Craswell and Taylor, 1992). The rationale of this argument is that the marginal cost to management for providing additional information may be much lower than the cost to individual equity holders in ascertaining the same information. This is particularly so in the case of individual equity shareholders trying to ascertain the reasons for changes in financial performance and the position of the company from the statutory accounts. Complementary narrative commentary of changes from the previous year in an annual report will save individual investors the cost of ascertaining such information. The predicted relationship is negative because the conflict between shareholders and directors increases as the percentage of share capital held by directors decreases (e.g. Dhaliwal, Salamon and Smith, 1982).

In the UK, a substantial investor is any person or organisation holding 3 percent or more of the share capital. UK institutional investors - primarily pension funds and life insurance companies - are key participants in UK equity markets, controlling around $45 \%$ of quoted investments (Myers, 2000). Institutions as major equity holders are potentially able to play a key role in determining corporate policy and incentive structures, including the patterns of hiring, firing and remunerating both executive and non-executive directors (e.g. Agrawal and Mandelker, 1990). This may include regular requests for information from company management which may not be cost-effective from a managerial point of view. This may result in managers providing more complementary narrative information in annual reports. There are, however, reasons for believing that the potential for institutional involvement may not be fulfilled, not least because the private cost of such intervention may yield private benefits which are less than the public good they will 
produce (Cosh, Hughes and Singh, 1989). If the role that institutional investors choose to play is passive, exercising 'exit' rather than 'voice', then their influence may not lead to greater complementary narrative disclosure levels. Based on the above arguments, the following hypotheses will be tested:

$H_{6}$ : There is a negative relationship between executive directors' share ownership and the extent of complementary narrative commentary of statutory accounts.

$H_{7}$ : $\quad$ There is a positive relationship between substantial institutional investors and the extent of complementary narrative commentary of statutory accounts.

\subsection{Governance-Related Variables}

Previous studies have suggested that the extent of disclosure by firms may vary because of differences in the independent auditors (e.g. Gibbins, Richardson and Waterhouse, 1990). Malone et al. (1993) suggested that the rationale behind this is the expectation that smaller audit firms (non big-five) are often sensitive to client demands because of economic consequences. Based on this reasoning, Wallace and Naser (1995, p. 326) suggested that bigger, independent audit firms are less likely than smaller independent ones to depend on (or have a bonding relationship with) one or a few clients. The lack of bonding with clients would enable big independent audit firms to demand greater disclosure detail in annual reports of their clients (see also Watts and Zimmerman, 1983).

A number of the most influential suggestions for the reform of corporate governance are built around the influence and role of non-executive directors (Charkham, 1994). Non-executive directors provide advice to corporate boards on strategic decisions, which may improve economic and financial performance (Fama, 1980). Specifically, a higher proportion of non-executive directors on corporate boards would result in more effective monitoring and limit managerial 
opportunism (Fama and Jensen, 1983). Since non-executive directors should be independent (Higgs Report, 2003), they may be inclined to encourage managers to become more responsive to investors' information needs. The inclusion of non-executive directors on boards will improve a firm's compliance with disclosure requirements which in turn will enhance the comprehensiveness and quality of disclosure (e.g. Mangena and Pike, 2005). Chen and Jaggi (2000) examined whether a higher proportion of non-executive directors on corporate boards is associated with more comprehensive disclosure within the mandatory framework. Their results suggest a positive association between the proportion of non-executive directors on corporate boards of Hong Kong firms and comprehensiveness of financial disclosure. Based on the preceding discussion, the following other hypotheses will be tested:

$H_{8:} \quad$ There is a positive relationship between auditors (big-five) and the extent of complementary narrative commentary of statutory accounts.

$H_{9}$ : There is a positive relationship between the proportion of non-executive directors and the extent of complementary narrative commentary of statutory accounts.

\section{Data and Research Method}

\subsection{Sample selection}

A sample of 200 out of all 1115 UK non-financial companies listed on the London Stock Exchange was randomly selected. Financial companies were excluded from the population of listed companies before sampling because they are required to provide additional disclosures by other regulatory bodies (Tauringana, 1997; Mangena and Pike, 2005). The latest annual reports as at 31 December 2002 were requested. Eleven companies did not respond and subsequent efforts to find their annual reports, including visits to company websites, were unsuccessful. Eight companies were eliminated because they had changed their accounting 
periods. This meant that their financial year was either shorter or longer than the rest which would have caused comparison problems. Six were removed because they had recently merged with other companies, while five letters were returned because addresses had been changed. The final sample consisted of 170 companies.

\subsection{Disclosure Index and Scoring Approach}

The complementary narrative commentary index consists of items which are required to be disclosed in statutory accounts (profit and loss and balance sheet) of annual reports in terms of the UK Companies Act 1985 and Accounting Standards and the London Stock Exchange (see appendix I). The annual reports were scored by awarding a 1 if a complementary narrative commentary of statutory accounts numbers was provided in the narrative parts of the annual report and 0 if it was not (e.g. Cooke, 1991). For example, if the narrative part of the annual report discussed the increase in turnover, the company would be awarded 1 and if not 0 . In the end the individual company score is determined by how many accounting numbers presented in the profit and loss account were discussed divided the maximum possible for the company. The maximum number of items possible may differ because particular numbers may not be relevant or disclosed in other companies’ annual reports. For example, for companies with no debt on their balance sheet, the item 'interest payable' will not appear in the P\&L, and therefore the total possible for such a company will be reduced by the number of nonapplicable items. No weight was attached to take into account the usefulness of different items to different users. This is because prior studies (e.g., Mangena and Pike, 2005) show that there are no differences in the results between weighted and unweighted disclosures. According to Cooke (1992), companies that are good at disclosing useful items are equally good at disclosing less useful items. Unlike extant studies whereby a researcher needs to decide whether non-disclosure means the item is not applicable, there was no such problem in the case of the current research. This is because in the case of a complementary narrative commentary not being 
provided the statutory accounts were checked. If the item was included in the statutory accounts but there was no complementary narrative commentary in the narrative section, then the company was not awarded any mark.

\subsection{Estimating procedure}

Ordinary least squares (OLS) regression estimates were used to determine the influence of selected company variables on complementary narrative commentaries of statutory accounts. The following OLS regression estimation process is assumed to hold for the sample companies:

$$
\begin{aligned}
\text { CNCS }_{J}=\beta_{0}+ & \beta_{1} \text { LNSIZE }_{J}+\beta_{2} \text { GEAR }_{J}+\beta_{3} \text { PROFIT }_{J}+\beta_{4} \text { LIQUID }_{J} \\
& +\beta_{5} \text { EXCEPTS }_{J}+\beta_{6} \text { DIRSHA }_{J}+\beta_{7} \text { SUBINST }_{J} \\
& +\beta_{8} \text {.UVDIT }_{J}+\beta_{9} \text { PRONED }_{J}+E_{J}
\end{aligned}
$$

Where the dependent variable, $\mathrm{CNCS}_{J}$, is the complementary narrative commentary score (that is the score for each company divided by the maximum possible score), $\beta_{0}$ is the intercept, $e_{j}$ the residual and the independent variables $\beta_{1}$ to $\beta_{9}$ and are defined in Table 1 .

\section{INSERT TABLE 1 ABOUT HERE}

\section{Results and Discussion}

\subsection{Descriptive statistics}

The descriptive statistics of both the dependent and independent variables are presented in Table 2 showing the median, mean, standard deviation, minimum and 
maximum for the dependent and independent variables. The descriptive statistics of the complementary narrative commentary score (CNCS) show that the minimum is 0.00 which means that at least one company provided no commentary of the financial statement numbers. The mean score is $39.9 \%$ with a median of $42 \%$ suggest, on the face of it, that companies provide very little complementary narrative commentary on financial statements numbers. However, since this is the first study to investigate this it is difficult to say whether this level of complementary narrative commentary is sufficient for the information needs of users. The other consideration is that of materiality. Obviously companies can not be expected to provide narrative commentaries when the change to the financial statement numbers is immaterial.

\section{INSERT TABLE 2 ABOUT HERE}

\subsection{Correlation and Multicollinearity Analyses}

The Pearson product-moment coefficients for all variables are presented in Table 3 and show no high correlations among independent variables. This suggests that multicollinearity problems, which arise when there is a strong correlation between two or more predictors in a regression model, are unlikely. High levels of collinearity (0.8 or 0.9 according to Field, 2000) increase the probability that a good predictor of the outcome will be found to be insignificant and rejected from the model. As Table 3 indicates, there seems to be no serious problem of multicollinearity with the data.

\section{INSERT TABLE 3 ABOUT HERE}

\subsection{Results of multiple regression analysis}

The results of the OLS regression model ${ }^{2}$ are presented in Table 4. The results indicate that the model explains $61 \%$ of the variation in the quantity of complementary narrative

\footnotetext{
${ }^{2}$ Various checks and tests were carried out to ensure that the assumptions of the model were not violated. These included heteroscedasticity, Kolmogrov-Smirnov, Cook’s distance, Durbin-Watson. The checks and tests all indicated that there were no serious violations of the model assumptions.
} 
commentary of statutory accounts. The results indicate that company size, gearing, profitability, liquidity, the presence of exceptional items and substantial institutional investors are all significant explanatory variables of the extent of complementary narrative commentary of statutory accounts. The positive t-values suggest that large companies, highly geared, more profitable, high liquidity, and those reporting exceptional items and those with substantial institutional investment provide more complementary narrative commentary than others. However, executive directors' share ownership, auditor type and the proportion of nonexecutive directors are not significant explanatory variables.

\section{INSERT TABLE 4 ABOUT HERE}

The significant association between company size and the extent of complementary narrative commentary of statutory accounts is consistent with previous research findings which found that size influence the extent of disclosure in general (e.g.Wallace, Naser and Mora, 1994). This is also consistent with the notion that large companies are in the public eye and to satisfy their requirements they need to provide more information than smaller companies. The results also indicate that gearing is positively associated with the extent of complementary narrative commentary of statutory accounts, suggesting that high geared companies provide more commentary than low geared companies. This is consistent with previous research results reported by Malone et al (1993).

The significant positive association between profitability and the extent of complementary narrative commentary of statutory accounts suggests that more profitable companies discuss more of the accounting numbers from the profit and loss account than less profitable companies to signal superior performance. This is consistent with the signalling theory which suggests that more profitable companies are more likely to signal to the market their superior performance. The findings are also consistent with previous research findings by 
Tauringana and Chong (2004) who found that company managers are more likely to comment on good performance compared to bad. Similarly, liquidity ratio results which show a positive association with extent of narrative complementary commentary are consistent with agency theory prediction that managers want to be seen in good light and will volunteer information if it shows them in good light. The results of the presence of exceptional items are consistent with the argument in the hypothesis which states that the presence of exceptional items motivates managers to comment because failure to do so would lead to investor uncertainty about the future prospects of the company. Finally, the significance of the relationship between substantial institutional investors and the extent of complementary narrative commentary is consistent with the argument by Agrawal and Mandelker (1990) that Institutions as major equity holders are potentially able to play key role in corporate disclosure policy. The results presented in this study suggest that substantial institutional investors may put pressure on company managers to provide more complementary narrative discussion in annual reports.

\section{Summary and Concluding Remarks}

This study, for the first time, formally defined and classified narrative information into complementary and supplementary. Complementary narrative information is defined as that information which refers to specific numbers presented in the financial statements. On the other hand, supplementary information is defined as any other non-specific narrative information on matters such as future prospects, company's strategy, and operating environment. Having made the distinction the paper investigated the extent of complementary narrative commentary of statutory accounts of UK listed companies, and also examined the association of the complementary narrative commentaries with company specific factors. The findings of the extent of complementary narrative commentary suggest that, on average, companies provided a commentary on $39.9 \%$ of the items found in the statutory accounts. Whilst, the level of complementary commentary seems low, it is difficult to make conclusive judgements for two 
reasons. First this study is only exploratory. Second, the issues of materiality were not addressed in the study. The results also indicated that company size, gearing, profitability, liquidity ratio, substantial institutional investment, the presence of exceptional items determine the extent of complementary narrative commentary. Directors' share ownership, auditor type and the proportion of non-executive directors were found not to have an influence on the extent of complementary narrative commentary of statutory accounts.

We believe the study results are important to policy makers, users of annual reports and provide the basis for further research that may lead to improvement in the quality of financial reporting. The study is significant to policy makers because it distinguishes for the first time complementary from supplementary narrative information. The distinction is important because in our view it is relatively easier for policy makers to legislate for complementary narrative information and enforce compliance compared to supplementary narrative information. Given that our findings suggests that on average only $39.9 \%$ of the numbers in statutory accounts are commented on, accounting regulators may wish to legislate for more complementary narrative commentaries if future research find that complementary narrative commentaries are not sufficient for the information needs of users of the annual report. We also believe that this study, the first to focus on complementary narrative commentary, is important to unsophisticated shareholders who do not understand financial statements and have to rely on management complementary narrative commentaries. Sophisticated users such as investment analysts will also benefit as they try to understand factors affecting current results in order to predict future results. Finally, the study is important because future research suggested below may lead to improvements in the quality of financial reporting.

There are a number of limitations which should be taken into account in the interpretation of the current results. First, the scoring procedure adopted is dichotomous. This means no account is taken of the comprehensiveness of complementary narrative commentary. This 
penalises those companies that provide more detailed discussion. However, a detailed review of literature indicated that there was no consensus on the best way to measure the amount of information. Given that the majority of studies on the extent of information disclosure have used the same scoring procedure it was deemed the best available method available. Second, in some cases there were difficulties in deciding what is complementary and supplementary. This problem was alleviated by independent scoring by authors and then discussing the differences until a satisfactory resolution was reached. Finally, the results reported in this paper are based on complementary narrative commentary of the statutory accounts rather than all financial statements which include the Statement of Total Recognised Gains and Losses (SORG) and the Cash Flow Statement. However, given the preliminary nature of the work it was necessary to limit the scope.

The preliminary nature of the study suggests that more research is required. First, there is need for further research as to the validity of classifying narrative information into complementary and supplementary. Second, there is need for research into the relative usefulness of complementary narrative and supplementary narrative information to the users of annual reports. This is because if there is a difference in the usefulness of complementary and supplementary information there may be need for a rebalancing in favour of the information that is more useful. Finally, there is need for research to find out whether complementary narrative information is relatively easier to legislate and enforce compliance as we suggested in this paper. 


\section{References}

Abrahamson, E. and Amir, E. (1996), 'The Information Content of the President's Letter to Shareholders', Journal of Business Finance \& Accounting, Vol 23 , No 8, pp. 1157-1180.

Accounting Standards Board, (1993), Operating and Financial Review, Accounting Standards Board, London.

Accounting Standards Board, (1999), Statement of Principles, Accounting Standards Board, London.

Accounting Standards Board. (2003), Operating and Financial Review. Accounting Standards Board, London.

Accounting Standards Board. (2005). Reporting Standard 1 - Operating and Financial Review. Accounting Standards Board, London.

Accounting Standards Board. (2006). Reporting Statement 1 - Operating and Financial Review. Accounting Standards Board, London.

Agrawal, A., Mandelker, G.N. (1990), 'Large Shareholders and the Monitoring of Managers: The Case of Anti-take-over Charter Amendments', Journal of Financial and Quantitative Analysis, Vol. 25, No.2, pp. 143-60.

Akerlof, G.A. (1970), 'The Market for "Lemons": Quality Uncertainty and the Market Mechanism', Quarterly Journal of Economics, Vol. 84, pp. 488-500.

Anderson, R.H. 1979. The Usefulness of Annual Reports to Australian Investors, A paper presented at the Accounting Association of Australia and New Zealand Conference. University of Melbourne, Australia.

Arthur Andersen, (1996), What's the Story: A Survey of Narrative Reporting in Annual Reports. Arthur Andersen, London.

Arthur Andersen, (2001), Spice up the Story: A Survey of Narrative Reporting in Annual Reports. Arthur Andersen, London.

Bamber, L.S. and Cheon, Y.S. (1998), 'Discretionary management earnings forecast disclosures: Antecedents and outcomes associated with forecast venue and forecast specificity choices', Journal of Accounting Research, Vol. 36, No.2, pp.167-190.

Barron, O.E. and Kile, C.O. (1999), 'M D\& A Quality as Measured by SEC and Analysts' Earnings Forecasts’, Contemporary Accounting Research, Vol.16, No.1, pp. 75-109.

Bartlett, S.A. and Chandler, R.A. (1997), 'The Corporate Report and the Private Shareholder: Lee and Tweedie Twenty Years On’, British Accounting Review, Vol. 29, pp. 245-261.

Beattie, V. (1999), Business Reporting: The Inevitable Change? Institute of Chartered Accountants of Scotland, Edinburgh. 
Beattie, V., McInnes, B., and Fearnley, S. (2004), Through the eyes of Management: narrative reporting across three sectors, Institute of Chartered Accountants in England and Wales,

Belkaoui, A.and Kahl, A. (1978), Corporate Financial Disclosure in Canada. Research Monogram No.1, Canadian Certified General Accountants Association, Vancouver.

Botosan, C.A. and Harris, M. (2000), 'Motivations for a change in disclosure frequency and its consequences: an examination of voluntary quarterly segment disclosures', Journal of Accounting Research, Vol. 38, No. 2, pp. 329-353.

Buzby, S.L. (1975), 'Company Size, Listed versus Unlisted Stocks and the Extent of Financial Disclosure’, Journal of Accounting Research, Vol. 13, No. 1, pp. 16-37.

Charkham, J. (1994), 'A larger role for institutional investors', In Dimsdale, $\mathrm{N}$ and Prevezer, M., (Eds.), Capital markets and corporate governance. Oxford: Claredon Press, pp. 99-110.

Chen, C.J.P. and Jaggi, B. (2000). 'Association between independent non-executive directors, family control and financial disclosure in Hong Kong', Journal of Accounting and Public Policy, Vol. 19, pp. 285-310.

Chow, C.W. (1982), 'The Demand for External Auditing: Size, Debt and Ownership Influences’, The Accounting Review, Vol. 57, No. 2 , pp. 272-329.

Clarkson, P.N.M., Kao, J.L. and Richardson, G.D. (1999), 'Evidence That Management Discussion and Analysis (MD\&A) is a Part of a Firm's Overall Disclosure Package', Contemporary Accounting Research, Vol. 16, No.1, pp. 11-134.

Cole, C.J., and Jones, C.L. (2005), 'Management Discussion and Analysis: A Review and Implications for Future Research’, Journal of Accounting Literature, Vol. 24, pp. 135-174.

Cooke, T.E. (1991), 'An Assessment of Voluntary Disclosure in Annual Reports of Japanese Corporations’, International Journal of Accounting, Vol.26, No. 3, pp. 174-89.

Cooke, T.E. (1992), 'The Impact of Size, Stock market Listing and Industry Type on Disclosure in the Annual reports of Japanese Listed Corporations', Accounting and Business Research, Vol. 22, No. 87, pp. 229-237.

Cosh, A.D., Hughes, A., Lee, K. Singh, A. (1989), 'Institutional investment mergers and the market for corporate control', International Journal of Industrial Organisation, Vol. 1, No.7, pp. 73-100.

Courtis, J.K. 1982. Private Shareholder response to corporate annual reports. Accounting and Finance, Vol 22, pp. 53-72.

Craswell, A.T. and Taylor, S.L. (1992). 'Discretionary Disclosure of Reserves by Oil and Gas Companies: An Economic Analysis', Journal of Business Finance and Accounting, Vol. 19, No 2, pp. 295-308. 
Dhaliwal, D., Salamon, G. and Smith, E. (1982), 'The Effect of Owner Versus Management Control on the Choice of Accounting Methods', Journal of Accounting and Economics, Vol 4 No. 1, pp. 41-53.

Diamond, D. (1985), 'Optimal Release of Information by Firms', Journal of Finance, Vol. 4, No. 4, pp. 1071-1094.

Diamond, D.W. and Verrechia, R.E. (1991), 'Disclosure, Liquidity, and Cost of Capital', Journal of Finance, Vol. 46, 4, pp. 1325-1359.

El-Gazzar, S.M., Finn, P.M. and Jacob, R, (1999), 'An empirical investigation of multinational Firms's compliance with international accounting standards', International Journal of Accounting Vol. 34, No.2, 239-248.

Fama, E.F. (1980), 'Agency Problems and theory of the firm', Journal of Political Economy, Vol. 88, No.2, pp. 288-307.

Fama, E.F. and Jensen, M.C. (1983), 'Separation of ownership and control', Journal of Law and Economics, Vol. 26, No. 2, pp. 301-325.

Field, A. (2000), Discovering Statistic Using SPSS for Windows, Sage Publications.

Firth, M. (1979), 'Impact of Size, Stock Market Listing and Auditors on Voluntary Disclosure in Annual Reports’, Accounting and Business Research, Vol. 9, No. 36, pp. 273-280.

Financial Reporting Standards 3 (FRS 3) Reporting Financial Performance. Accounting Standards Board, London.

Gagnon, J.M. (1971), 'The Purchase-Pooling Choice: Some Empirical Evidence', Journal of Accounting Research, Spring, pp. 52-72.

Gibbins, M., Richardson, A. and Waterhouse, J. (1990), 'The Management of Financial Disclosure: Opportunism, Ritualism, Policies and Processes', Journal of Accounting Research, Vol. 28, No. 1, pp. 121- 143.

Haniffa, R.M. and Cooke, T.E. (2002), 'Culture, Corporate Governance and Disclosure in Malaysian Corporations’, Abacus, Vol. 38, No. 3, pp. 317-349.

Higgs Report, (2003), Review of the role and effectiveness of non-executive directors, The Department of Trade and Industry, London.

Kim, O. and Verrecchia, R.E. (1994), 'Market liquidity and volume around earnings Announcements’, Journal of Accounting and Economics, Vol. 17, pp. 41-67.

Klaassen, J and Schreuder, H. 1981. Corporate Report Readership and Usage in the Netherlands. Maandblad voor Accountancy en Bedreifshuishoudkunde, Amsterdam, Vol. 55, Vol. (2/3), pp.101-117.

Lang, M. and Lundholm, R. (1993), 'Cross-Sectional Determinants of Analysts Rating of Corporate Disclosures’, Journal of Accounting Research, Vol. 31, No. 2, pp. 246-271. 
Lee, T.A. and Tweedie, D.P. 1976. The Private Shareholder: His Sources of Financial Information and His Understanding of Reporting Practices. Accounting and Business Research 6 (24): 304-314.

Lee, T.A. and Tweedie, D.P. (1981), The Institutional Investor and Financial Information, The Research Committee of The Institute of Chartered Accountants in England and Wales, London.

Leftwich, R.W., Watts, R.L. and Zimmerman, J.L. (1981), 'Voluntary corporate Disclosure: The Case of interim reporting’, Journal of Accounting Research, Vol. 19, Supplement, pp. 50-77.

Malone, D., Fries, C. and Jones, T. (1993), 'An empirical investigation of the extent of Corporate financial disclosure in the oil and gas industry', Journal of Accounting, Auditing and Finance, Vol. 8, No. 3, pp. 249-273.

Mangena, M. and Pike, R. (2005), 'The effect of audit committee shareholding, financial expertise and size on interim financial disclosures', Accounting and Business Research, Vol. 35, No. 4, pp. 107-130.

Milgron , P.R. (1981), 'Good News and Bad News: Representation Theorems and Applications', The Bell Journal of Economics, Vol. 12, No. 2, pp. 380-391.

Milne, M.J. and Chan, C.C.C. (1999), ' Narrative Corporate Social Disclosures: How Much of a Difference Do They Make To Investment Decision-Making?’, British Accounting Review, Vol. 31, pp. 439-457.

Myers, P. (2000), The Myers Review of Institutional Investment for HM Treasury. $\underline{\text { HM }}$ Teasury, London.

Myers, S.C. (1971), 'Determinants of corporate borrowing', Journal of Financial Economics, Vol. 5, No. 2, 147-175.

Rogers, R.K. and Grant, J. (1997), 'Content Analysis of information cited in reports of sell-side financial analysts’, Journal of Financial Statement Analysis, Fall, pp. 17-30.

Rutherford, B.A. (2002), 'The operating and Financial Review: Could Do Better, Could Say More', Accounting and Business, Vol. 5, No. 3, pp. 40-41.

Ronen, J. and Livnat, J. (1981), 'Incentives for Segmental Reporting', Journal of Accounting

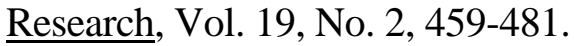

Securities and Exchange Commission, (2002), Commission Statement about Management's Discussion and Analysis of Financial Condition and Results of Operations (33-8056, 34-45321 and FR-61), SEC, Washington.

Skinner, D. (1994), 'Why firms voluntarily disclose bad news', Journal of Accounting Research, Vol. 32, pp. 38-60.

Smith, C.W. and Warner, J. (1979), 'On Financial Contracting: An Analysis of Bond Covenants', Journal of Financial Economics, No. 7, vol. 1, pp. 117-161. 
Smith, M., and Taffler, J. (2000), 'The Chairman's Statement - A content analysis of discretionary narrative disclosure', Accounting, Auditing and Accountability Journal, Vol. 13, No. 5, pp. 624646.

Stigler, G.L. (1971), ‘The Theory of Economic Regulation', Bell Journal of Economics and Management, Fall, pp. 3-21.

Tauringana, V. (1997), The Impact of Listing Status and Selected Company Characteristics on Voluntary Disclosure in the United Kingdom. Unpublished Doctoral Thesis, Napier University, Edinburgh, Scotland.

Tauringana, V. and Chong, G. (2004), 'Neutrality of Narrative Discussion in Annual Reports of UK Listed companies,' The Journal of Applied Accounting Research, Vol 7, No. 1, pp. 74-107.

Tennyson, B.M, Ingram, R.W. and Dugan, M.T. (1990), 'Assessing the information content of narrative disclosures in explaining bankruptcy’, Journal of Business Finance \& Accounting, 17, No. 3, 391-410.

Trucost, (2006), EU Accounts Modernisation Directive - Trucost Regulatory Guide, http://login.trucost.com/trucost/download/eu.pdf

Verrecchia, R.E. (1990), 'Information quality and discretionary disclosure’, Journal of Accounting and Economics, Vol. 12, pp. 365-80.

Wallace, R.S.O. and Naser, K. (1995), 'Firm-Specific Determinants of the Comprehensiveness of Mandatory Disclosure in the Corporate Annual Reports of Firms Listed on the Stock Exchange of Hong Kong', Journal of Accounting and Public Policy, Vol. 14, No. 4, pp. 311-368.

Wallace, R.S.O., Naser, K. and Mora, A. (1994). The Relationship Between Comprehensiveness Of Corporate Annual Reports and Firm Characteristics in Spain', Accounting and Business

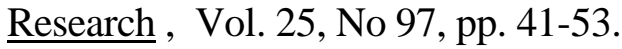

Watts, R.L. and Zimmerman, J.L. (1983), ‘Agency Problems, Auditing and Theory of A Firm: Some Evidence’, Journal of Law and Economics, October, pp. 613-634.

Wilson, J.H. and Allison-Koerber, D. (1992), ' Combining Subjective and Objective Forecasts Improve Results,' The Journal of Business Forecasting Methods and Systems, Vol. 11, No, 3, pp.3-8.

Wilton, R. L. and Tabb, J.B. (1978), 'An investigation into private shareholder usage of financial statements in New Zealand’, Accounting Education, May, pp 171.

Zarzeski, M.T. (1996), 'Spontaneous harmonization effects of culture and market forces on accounting disclosure practices’, Accounting Horizons, Vol.10, No. 1, pp.18-31. 
Appendix I

Complementary Narrative Commentary Scoring Sheet

Company Name

List of Items

1. Turnover

2. Cost of sales

3. Gross profit

4. $\quad$ Net operating expenses

5. Operating profit

6. Profit on sale of properties

7. Loss on sale of properties

8. Provision for loss on operations to be discontinued

9. Loss on disposal of discontinued operations

10. Profit on disposal of discontinued operations

11. Loss on ordinary activities before interest

12. Profit on ordinary activities before interest

13. Interest payable

14. Interest receivable

15. Profit on ordinary activities before taxation

16. Loss on ordinary activities before taxation

17. Tax on profit of ordinary activities

18. Profit on ordinary activities after taxation

19. Loss on ordinary activities after taxation

20. Minority interests

21. Profit for the financial year

22. Loss for the financial year

23. Dividends

24. Retained profit for the financial year

25. Retained loss for the financial year

26. Earnings per share

$27 \quad$ Fixed assets (total)

28. Tangible fixed assets (total)

29. Intangible fixed (total)

30. Current assets (total)

31. Stocks

32. Debtors

33. Cash at bank and in hand

34. Prepayments

35. Creditors: amounts failing due within one year

36. Provision for corporation tax

37. Accrued charges

38. Bank overdraft

39. Net current assets

40. Total assets less current liabilities

41. Creditors: amounts falling due after more than one year

42. Debentures

43. Capital and reserves (total)

44. Share capital

45. Share premium

46. Accumulated profit and loss account 
Table 1: Description of Variables

Symbol Variable description

$\beta_{1} \quad$ Size of a company is measured by total assets expressed in $£$ millions.

$\beta_{2} \quad$ Gearing - long term debt divided by long term loans plus shareholders' equity.

$\beta_{3} \quad$ Profitability - company's net profit before interest and tax divided by total assets.

$\beta_{4} \quad$ Liquidity ratio - current assets divided by current liabilities.

$\beta_{5} \quad$ Exceptional items - a dummy variable coded 1 if the reported exceptional items in its profit and loss account; 0 otherwise.

$\beta_{6} \quad$ Directors share ownership - the percentage of voting shares owned or controlled by directors including any shares held on behalf of family members but excludes any shares held in trust.

$\beta_{7} \quad$ Substantial institutional investors - the percentage of equity owned by substantial institutional investors.

$\beta_{8} \quad$ Large auditors - a dummy variable coded as 1 if the company's auditor is a member of one of the "big five" firm of auditors; 0 otherwise.

$\beta_{9} \quad$ Non-executive directors - the number of non-executive directors proned $\left(^{+}\right)$ divided by the total number of all directors on the company's board of directors.
Acronym

and expected

sign

size $\quad(+)$

gear $(-/+)$

profit $(+)$

liquid $(+)$

excepts $(+)$

dirsha $(-)$

subinst $(+)$

audit $(+)$

Table 2: Descriptive Statistics for Dependent and Independent Variables

\begin{tabular}{lcccccc}
\hline Variable & Obs & Meadian & Mean & Std. Dev. & \multicolumn{1}{c}{ Min } & Max \\
\hline Cncs & 170 & .42 & .399 & .151 & .00 & .82 \\
Size & 170 & 95527 & 675023 & 1854097 & 731.00 & 16278000 \\
Gear & 170 & .26 & .284 & .209 & .00 & .92 \\
Profit & 170 & .0993 & .085 & .105 & -.43 & .36 \\
Liquid & 170 & 1.395 & 1.509 & .765 & .24 & 4.15 \\
Excepts & 170 & .00 & .247 & .433 & .00 & 1.00 \\
Dirsha & 170 & .571 & .135 & .179 & .00 & .75 \\
Subinst & 170 & .3990 & .389 & .177 & .00 & .80 \\
Audit & 170 & .00 & .477 & .501 & .00 & 1.00 \\
Proned & 170 & .40 & .410 & .140 & .00 & .78 \\
\hline
\end{tabular}


Table 4: OLS Regression Results

Number of obs $=170 ; F=30.292 ;$ Prob $>0.000 ; R^{2}=0.630 ;$ Adj $R^{2} .609 ;$ MSE = .09404;

Durbin Watson $=1.808$

\begin{tabular}{|c|c|c|c|c|c|c|c|}
\hline Source & \multicolumn{3}{|c|}{ SS } & $\overline{d f}$ & \multicolumn{3}{|c|}{ MS } \\
\hline Model & \multicolumn{3}{|c|}{2.411} & 9 & \multicolumn{3}{|c|}{.268} \\
\hline Residual & \multicolumn{3}{|c|}{1.415} & 160 & \multirow{2}{*}{\multicolumn{3}{|c|}{.009}} \\
\hline Total & \multicolumn{3}{|c|}{3.826} & 169 & & & \\
\hline Cncs & Coef. & Std err & t-value & Sig & $\begin{array}{r}95 \% \mathrm{C} \\
\text { Lower Bo }\end{array}$ & rval & VIF \\
\hline$\overline{\text { (Constant) }}$ & -.2140 & .064 & -3.360 & .001 & -.340 & -.088 & \\
\hline Size & .0302 & .005 & 6.451 & .000 & .021 & .039 & 1.358 \\
\hline Gear & .1790 & .037 & 4.817 & .000 & .106 & .252 & 1.149 \\
\hline Profit & .4570 & .071 & 6.402 & .000 & .316 & .598 & 1.069 \\
\hline Liquid & .0680 & .010 & 6.983 & .000 & .049 & .087 & 1.060 \\
\hline Excepts & .0412 & .017 & 2.403 & .017 & .007 & .075 & 1.051 \\
\hline Dirsha & .0016 & .046 & .034 & .973 & -.089 & .092 & 1.274 \\
\hline Subinst & .106 & .043 & 2.452 & .015 & .021 & .192 & 1.124 \\
\hline Audit & -.0004 & .015 & -.025 & .980 & -.030 & .029 & 1.054 \\
\hline Proned & .0420 & .054 & .780 & .436 & -.064 & .148 & 1.082 \\
\hline Mean VIF & & & & & & & 1.136 \\
\hline
\end{tabular}


Table 3: Pearson Correlations Between Company Characteristics and Narrative Discussion Index

\begin{tabular}{|c|c|c|c|c|c|c|c|c|c|c|}
\hline & Cncs & Assets & Gear & Profit & Liquid & Excepts & Dirsha & Subinst & Audit & Proned \\
\hline Cncs & 1.000 & & & & & & & & & \\
\hline Assets & $.528 * *$ & 1.000 & & & & & & & & \\
\hline Gear & $.440 * *$ & $.276 * *$ & 1.000 & & & & & & & \\
\hline Profit & $.445^{* *}$ & .148 & $.198 *$ & 1.000 & & & & & & \\
\hline Liquid & $.431 * *$ & .140 & .026 & .072 & 1.000 & & & & & \\
\hline Exceps & .090 & .019 & .015 & -.045 & -.083 & 1.000 & & & & \\
\hline Dirsha & $-.226 * *$ & $-.374 * *$ & -.067 & -.100 & -.047 & .030 & 1.000 & & & \\
\hline Subinst & $.203^{* *}$ & -.038 & .133 & .049 & .137 & -.019 & $-.206 * *$ & 1.000 & & \\
\hline Audit & .008 & -.083 & .017 & .090 & .041 & -.137 & -.048 & .098 & 1.000 & \\
\hline Proned & .097 & $.158 *$ & .057 & -.023 & -.059 & $.160^{*}$ & $-.160 *$ & -.033 & -.098 & 1.000 \\
\hline
\end{tabular}

$* *=$ Pearson Coefficient of correlation is significant at $1 \%$ level (2-tailed). $*=$ Pearson Correlation is significant at $5 \%$ level (2-tailed). 